\title{
Assessment of presence and distribution of Armillaria and Heterobasidion root rot fungi in the forest of Vallombrosa (Apennines Mountains, Italy) after severe windstorm damage
}

\author{
László Benedek Dálya ${ }^{(1)}$, \\ Paolo Capretti ${ }^{(2)}$, \\ Luisa Ghelardini ${ }^{(2)}$, \\ Libor Jankovský (1)
}

(1) Department of Forest Protection and Wildlife Management, Mendel University in Brno (ÚOLM), Zemedelská 3, 61300 Brno (Czech Republic); (2) Department of Agrifood Production and Environmental Sciences, University of Florence (DISPAA), p.le delle Cascine 28, I-50144, Firenze (Italy)

@ László Benedek Dálya

(laszlo.dalya@mendelu.cz)

Received: Jul 22, 2018 - Accepted: Dec 28, 2018

Citation: Dálya LB, Capretti P, Ghelardini L, Jankovský L (2019). Assessment of presence and distribution of Armillaria and Heterobasidion root rot fungi in the forest of Vallombrosa (Apennines Mountains, Italy) after severe windstorm damage. iForest 12: 118124. - doi: 10.3832/ifor2929-012 [online 2019-02-11]

Communicated by: Alberto Santini
One of the main problems for the management and conservation of silver fir stands has long been pathogens causing root rot, in particular Armillaria spp. and Heterobasidion annosum s.l. These opportunistic pathogens are especially threatening now that climate change related stress is increasing tree susceptibility to disease and vulnerability to windstorms. The northern Apennines Mountains (central Italy) are forecast to be one of the areas with the highest temperature increase in the next future. However, no systematic assessment exists of the risk posed by the disturbance due to secondary pathogens in the Apennine forests. In the Nature Reserve of Vallombrosa (northern Apennines), where silver fir forests have been managed and conserved for centuries since the Middle Ages, making it an ideal site for studying these parasites, the high presence of $H$. annosum was reported already in 1990, while only sporadic observations are available on Armillaria species. The aim of this work was to examine the occurrence of both pathogens, since detailed knowledge about their distribution may assist forest management planning and decision-making. Systematic sampling was undertaken at the intersection of 52 grid points covering the whole forest. Different fungal species from soil and fungal samples (fruiting bodies or rhizomorphs) were identified by combining morphological descriptions with molecular methods. The analyses confirmed the presence of $H$. abietinum in about $70 \%$ of the investigated points. The fungus was detected at two new localities above 1000 metres suggesting a possible expansion of the parasite at upward elevation, which might be associated with climate change. Armillaria was widespread: almost $90 \%$ of the samples resulted positive, and four different Armillaria species were successfully identified. The most frequent species were $A$. cepistipes, whose rhizomorphs were especially abundant, and $A$. ostoyae, which was often detected just in soil samples. At sites where $A$. cepistipes was found to coexist with $A$. gallica, these two species might specialize themselves to necrotrophic and saprotrophic lifestyle, respectively. Besides, there were unexpected findings of $A$. mellea, supposed to be a residual from the previous rotation of broadleaves.

Keywords: Abies alba, Armillaria spp., Butt Rot, Climate Change Disturbances, Heterobasidion annosum, Root Rot, Silver Fir, Windstorm Damage

\section{Introduction}

Heterobasidion annosum s.l. (Fr.) Bref. 2018).

and Armillaria species are among the most $H$. annosum s.l. had long been regarded as destructive forest pathogens in many parts a single species until mating tests revealed of the world. As facultative necrotrophs, the occurrence of intersterility groups these parasitic fungi are able to survive (ISGs - Korhonen 1978b), all of which have saprotrophically on dead wood, and the later obtained formal description as spesame individual can switch from one mode cies. The Eurasian groups were named $\mathrm{H}$. of lifestyle to the other (Guillaumin \& Le- annosum s.s., H. abietinum Niemelä \& Kogrand 2013). Both species complexes cause rhonen and H. parviporum Niemelä \& Koroot rot and decay of the stem, which typically leads to uprooting under intense mechanical stress (Honkaniemi et al. 2017), as a consequence of the decreased stability of the tree. Such damages, which are typical in conifer plantations, took place after the windstorm of March $5^{\text {th }}, 2015$, which destroyed about 50 ha of forest at the Nature Reserve of Vallombrosa (central Italy). This event gave actuality to a complex monitoring in order to shed light on the key factors determining the susceptibility of the forest rhonen (Niemelä \& Korhonen 1998). H. annosum s.s. is mostly associated with pines, especially Scots pine (Pinus sylvestris L.), but attacks several other conifers and even some broadleaved tree species. H. parviporum shows a relatively strict specialization for Norway spruce (Picea abies Karst.), while $H$. abietinum is commonly associated with European silver fir (Abies alba Mill.) and other species of the genus Abies (Gonthier \& Thor 2013). Root and butt rot caused by Heterobasidion is widespread in 
coniferous forests of Italy. Along the Apennines, the disease incidence is particularly high in silver fir plantations that are older than 50-60 years (Capretti 1998). High economic losses associated with the pathogen have been reported from this area for decades, along with the dieback of fir stands (Cantiani 1960, Moriondo \& Tiberi 2000). Typically, the epidemic begins right after the first thinning, because the remaining live stumps are a favourable substrate for the vegetative spread of the parasite (Certini et al. 2000). Farina et al. (1990) reported the massive presence of $\mathrm{H}$. abietinum in the forest of Vallombrosa, performing a systematic sampling of the whole area. Their findings imply that root rot is a chronic disease in fir stands, and likely among the most important factors of the species' decline and high vulnerability to windstorms.

The genus Armillaria is distributed in all continents. In Europe, seven biological species have been distinguished based on sexual incompatibility (Korhonen 1978a, Guillaumin et al. 1993). Their geographical distribution has been detailed by Guillaumin et al. (1993). A. mellea (Vahl:Fr.) Kummer is distributed in the Atlantic and Mediterranean parts of Europe, in various deciduous forests (Shaw \& Kile 1991). A. ostoyae (Romagn.) Herink is less thermophilic and fundamentally linked to conifers (Shaw \& Kile 1991, Guillaumin \& Legrand 2013). A. borealis Marxm. \& Korhonen mainly populates coniferous forests of Northern Europe (Guillaumin \& Legrand 2013), but it is also common in highlands of Central Europe (Jankovsky 2003). A. gallica Marxm. \& Romagn. is regarded as a low-elevation species typical of floodplain forests, while
A. cepistipes Velen. occurs most frequently in the zone of European beech (Fagus sylvatica L. - Shaw \& Kile 1991, Jankovsky 2003, Antonín et al. 2009). A. socialis (DC.: Fr.) Fayod, frequently mentioned as $A$. tabescens in the literature, is a thermophilic species of Southern Europe (Antonín et al. 2006). A. ectypa (Fr.) Lamoure is confined to wetlands and extremely rare (Svetasheva 2015). Identification of the various Armillaria spp. present on a site can be of great practical importance because the virulence and host range markedly differ among species. The most pathogenic European species seem to be $A$. ostoyae and $A$. mellea (Guillaumin \& Legrand 2013). According to the scheme of Manion (1981), Armillaria spp. appear sometimes as a predisposing factor, through numerous early infections of the root systems, and sometimes as a contributing factor giving the deathblow to weakened trees, as in fir stands of Vallombrosa (Intini 1988).

Under current and projected changes in climatic conditions, Armillaria species are expected to increase their activity and rhizomorphogenic capacity, and more easily defeat tree defence (Haavik et al. 2015, Kubiak et al. 2017, Holuša et al. 2018). Tree vulnerability to Heterobasidion species is also expected to rise in a warmer climate because of increased fungal growth and sporulation rate (La Porta et al. 2008, Gori et al. 2013, Müller et al. 2014). More generally, climate change might exacerbate drought stress, increasing tree susceptibility to secondary pathogens (Ghelardini et al. 2016), including Heterobasidion and Armillaria species. Considering that increased windstorm damages in the forest of Vallombrosa (Chirici et al. 2018), as in European

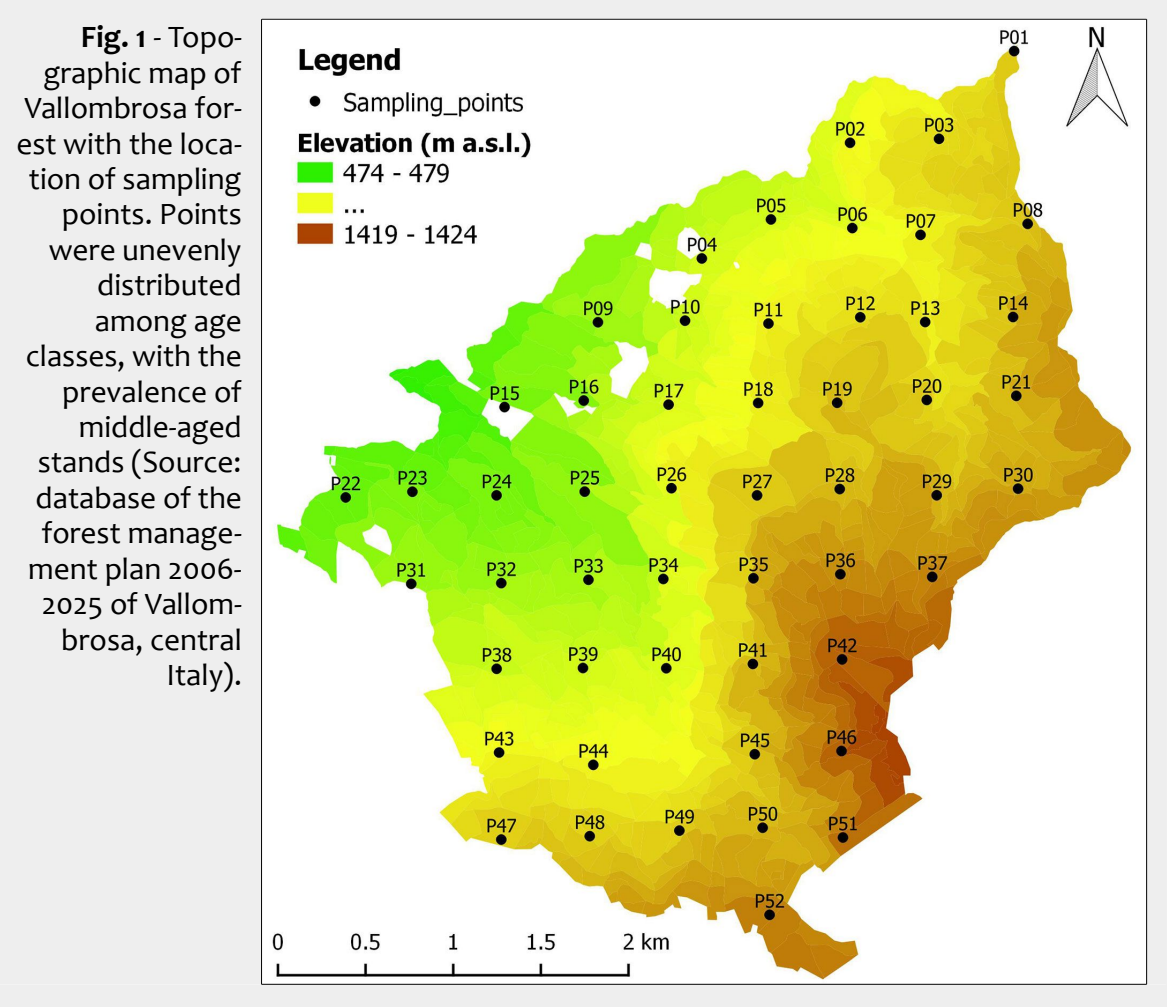

forests in general (Gregow et al. 2017), may be exacerbated by higher occurrence and/ or virulence of root rot pathogens, the goal of present work was to provide distribution maps of Armillaria and Heterobasidion species in the area to support forest managers in planning and decision-making. The several DNA-based diagnostic techniques, which were developed since the past studies on root rots in Vallombrosa, allowed for a more straightforward identification of wood rotting fungi in this work.

\section{Material and methods}

\section{Data acquisition}

The study area is the forest of Vallombrosa ( $\left.43^{\circ} 44^{\prime} \mathrm{N}, 11^{\circ} 34^{\prime} \mathrm{E}\right)$, a biogenetic reserve located about $50 \mathrm{~km}$ east-southeast of Florence, Tuscany, Italy. The forest covers 1273 ha in the northern Apennines Mountains. The climate is characterized by a mean annual air temperature of $9.8^{\circ} \mathrm{C}$ and a mean annual precipitation of 1275 $\mathrm{mm}$ (thermopluviometric station of Vallombrosa, $980 \mathrm{~m}$ a.s.l.). Western and northwestern slopes dominate, with an average inclination of $18.8 \%$. The altitude ranges between 470 and $1440 \mathrm{~m}$ a.s.l. The soil units belong to Inceptisols and Alfisols (Soil Survey Staff 1999), formed on Oligocene sandstone. Fragipan soil layers are present in $30 \%$ of the area, close to the surface (Bolla 2001). Silver fir has been cultivated since the $11^{\text {th }}$ century and occupies more than half of the area today. The native vegetation is mainly represented by beech at higher elevations, oak-hornbeam stands (Quercus spp. mixed with Carpinus betulus L. and Ostrya carpinifolia Scop.) and chestnut (Castanea sativa Mill.) at lower altitudes. Another important change is the introduction of European black pine (Pinus nigra Arn. ssp. nigra and Pinus nigra Arn. ssp. laricio), and to a lesser extent, coast Douglas-fir (Pseudotsuga menziesii [Mirb.] Franco var. menziesii) and Norway spruce.

Field surveys were carried out in July 2015. Since summer 2015 had been especially hot and dry, conditions that could restrict the formation of Heterobasidion fruiting bodies (Otrosina \& Garbelotto 2010), the survey was repeated in May 2017 for Heterobasidion. The area, where Abies alba dominated more than half of the stands (57.7\%), ahead of Pinus nigra (21.2\%) and $\mathrm{Fa}$ gus sylvatica $(13.5 \%)$ forests, was covered by a $500 \times 500 \mathrm{~m}$ grid which resulted in 52 sampling points (Fig. 1, Tab. S1 in Supplementary material). The same sampling grid has been used as in the study of Farina et al. (1990), so it was possible to compare the spatial distribution of $\mathrm{H}$. annosum s.l. over the past 28 years. Points were identified in the field with a handheld GPS navigator (Garmin ${ }^{T M}$ GPSMAP $^{\circledast}$ 62s, containing the forest management map of the Reserve) and a topographic map.

Soil sampling was done at all points, through hammering a steel cylinder of approximately $170 \mathrm{~cm}^{3}(8.5 \mathrm{~cm}$ high $\times 5 \mathrm{~cm}$ in- 
ner diameter) to the topmost layer of soil, excluding the organic horizon. Fruiting bodies of Heterobasidion and Armillaria rhizomorphs were collected in an area of about $300 \mathrm{~m}^{2}$ around the points. Samples were put into plastic bags or disposable plastic tubes and conserved at $4{ }^{\circ} \mathrm{C}$ until processed.

\section{DNA analysis}

All types of samples (Heterobasidion basidiomes, Armillaria rhizomorphs, and soil) were utilized for DNA extraction. Each soil sample was homogenized by mixing; fungal samples were homogenized by grinding the tissue in liquid nitrogen using sterile mortar and pestle. Approximately $0.25 \mathrm{~g}$ of samples was used. DNA was extracted using the PowerSoil ${ }^{\mathrm{TM}}$ DNA Isolation Kit (MoBio, Carlsbad, USA), according to the manufacturer's instructions. The extracted DNA solution was conserved at $-25^{\circ} \mathrm{C}$.

Morphological traits of basidiomes differ between species within $\mathrm{H}$. annosum s.l. as described by Mugnai \& Capretti (1989). For rapid confirmation of visual identification of $H$. annosum s.l., the taxon-specific competitive-priming (TSCP-)PCR method was used according to Gonthier et al. (2003). For amplifying DNA, a mix of four primers (MLS, MLF, Mito 5 and Mito 7) was applied. PCR was performed in a $25-\mu$ l reaction mixture containing approximately $50 \mathrm{ng}$ of template DNA, $0.5 \mu \mathrm{mol}$ of each primer, $5 \times$ MyTaq ${ }^{\oplus}$ Reaction Buffer (comprising dNTPs and $\mathrm{MgCl}_{2}$ in a final concentration of $1 \mathrm{mM}$ and $3 \mathrm{mM}$, respectively) and $1 \mathrm{U} \mathrm{MyTaq}^{\oplus}$ DNA Polymerase (Bioline, London, UK). The PCR was amplified using a Mastercycler $^{\circledast}$ ep Thermocycler (Eppendorf, Hamburg, Germany). The PCR programme was as follows: $3 \mathrm{~min}$ at $95^{\circ} \mathrm{C}$, followed by 35 cycles of $40 \mathrm{~s}$ at $95^{\circ} \mathrm{C}, 20 \mathrm{~s}$ at $64^{\circ} \mathrm{C}$ and $20 \mathrm{~s}$ at $72{ }^{\circ} \mathrm{C}$ with a final extension of $7 \mathrm{~min}$ at 72 ${ }^{\circ} \mathrm{C}$. Identification of $\mathrm{H}$. abietinum was confirmed by sequencing of the ITS region (Internal Transcribed Spacer) by the DNA Sequence Service of Macrogen Inc. (Seoul, Korea).

The ITS region was selectively amplified from soil and rhizomorph samples by nested PCR. The first reaction was carried out with external primers ITS1 and ITS4 used for amplification of ITS region of fungi (White et al. 1990). In the second reaction, the internal primers AR1 and AR2 for Armillaria ITS region were used (Lochman et al. 2004b). In both reactions, $1 \mu \mathrm{l}$ of isolated DNA was used. Reaction conditions were as described for TSCR-PCR. Amplifications were carried out in a Mastercycler ${ }^{\oplus}$ ep Thermocycler (Eppendorf, Hamburg, Germany) with thermal cycling parameters: initial denaturation at $94{ }^{\circ} \mathrm{C}$ for $2.5 \mathrm{~min}$, followed by 35 cycles of heat denaturation at $94{ }^{\circ} \mathrm{C}$ for $30 \mathrm{~s}$, annealing at $55^{\circ} \mathrm{C}$ for $40 \mathrm{~s}$, extension at $72{ }^{\circ} \mathrm{C}$ for $30 \mathrm{~s}$ and final extension at $72{ }^{\circ} \mathrm{C}$ for 5 min for ITS-PCR; initial denaturation at $94^{\circ} \mathrm{C}$ for $2.5 \mathrm{~min}$, followed by 35 cycles of heat denaturation at $94{ }^{\circ} \mathrm{C}$ for $30 \mathrm{~s}$, annealing at $60^{\circ} \mathrm{C}$ for $40 \mathrm{~s}$, extension at $72{ }^{\circ} \mathrm{C}$ for $30 \mathrm{~s}$ and final extension at $72{ }^{\circ} \mathrm{C}$ for 7 min for AR-PCR. In some cases, due to scarce visibility on agarose gel, it was necessary to repeat the PCR with higher volume $(2 \mu \mathrm{l})$ of extracted DNA. Negative samples were discarded after each reaction; positive ones were further processed. During restriction fragment length polymorphism (RFLP) analysis, DNA is cut into shorter strands by restriction enzymes that can be visualized after gel electrophoresis. Digestion of unpurified PCR products was carried out using restriction endonuclease Hinfl (Fermentas, Lithuania). As shown by Lochman et al. (2004a), this enzyme is able to discriminate the six main European $\mathrm{Ar}$ millaria species. The restriction mixtures containing $19 \mu$ l of PCR product with $1 \mu$ of buffer $R$ and $1 \mu$ of the enzyme Hinfl were incubated for $12 \mathrm{~h}$ at $37^{\circ} \mathrm{C}$ (Lochman et al. 2004b).

After each reaction, $P C R$ products were electrophoresed in agarose (Serva, Heidelberg, Germany) gel in TBE buffer at $5 \mathrm{~V} \mathrm{~cm}^{-1}$ for approximately $35 \mathrm{~min}$ (ITS, AR) or 80 min (TSCP, RFLP). $1 \%$ gel was used for simple identification (ITS, AR) and $2 \%$ gel for identification to the species level (TSCP, RFLP). One $\mu \mathrm{l}$ of ethidium bromide or Serva DNA Stain $G$ was added to the gel. Six $\mu$ l of each sample and control, as well as $3 \mu$ l of 100 bp DNA Ladder (New England BioLabs, Ipswich, MA, USA), to determine the fragment size, were mixed with loading dye (New England BioLabs) and loaded into the wells. In the case of RFLP-PCR products, DNA fragment sizes were estimated using $\Phi X_{174}$ DNA/Hinfl Marker (Fermentas) as DNA molecular size marker. Amplified DNA of $H$. annosum s.s. (for TSCP) and A. borealis (for ITS, AR and RFLP) served as positive controls. To visualize DNA fragments, the gel was placed on an ultraviolet transilluminator and documented by digital camera (Olympus ${ }^{\mathrm{TM}}$ (8080WZ, Japan).

\section{Data processing}

The mapping of sampling points was conducted using the QGIS 3.0.0 software. Spatial data transferred from GPS was linked with the collected attributive data in the

Tab. 1 - Number of stands with different tree species composition included in the study, and the incidence of Heterobasidion abietinum fruiting bodies in each stand type.

\begin{tabular}{lcc}
\hline Prevalent tree species & $\begin{array}{c}\text { Number } \\
\text { of stands }\end{array}$ & $\begin{array}{c}\text { H. abietinum } \\
\text { incidence (\%) }\end{array}$ \\
\hline A. alba & 21 & 100 \\
A. alba with conifers & 5 & 100 \\
A. alba with broadleaves & 4 & 100 \\
\hline P. nigra & 1 & 0 \\
P. nigra with conifers & 3 & 67 \\
P. nigra with broadleaves & 7 & 43 \\
\hline F. sylvatica & 7 & 29 \\
\hline Other broadleaves & 4 & 0 \\
\hline Total & 52 & 71 \\
\hline
\end{tabular}

program. After georeferencing each sampling location, thematic map layers were created. The effect of environmental factors (altitude, site fertility, soil type, prevalent tree species and age of forest stand) on the presence/absence of H. annosum s.l. was tested using binomial logistic regression. The influence of the above parameters on the detection frequency of different Armillaria spp. was tested by multinomial logistic regression. Species identified from soil and rhizomorphs were pooled for this analysis. Statistical analyses were performed using the software STATISTICA ${ }^{\circledR}$ ver. 12.0 (StatSoft 2013).

\section{Results}

Heterobasidion annosum s.l. fruiting bodies were found on Abies alba stumps (cut or uprooted) at $71 \%$ of the sampling points. The pathogen was present in $85 \%$ of conifer stands and in only two broadleaved ically). All samples were assigned to H. abietinum. The parasite was found in all silver fir stands, pure and mixed to other conifers (mainly European black pine and Douglasfir) or broadleaved species. Fruiting bodies of $\mathrm{H}$. abietinum were also present in about half of the stands where European black pine was the prevalent species. The findings of the present survey are summarized in Tab. 1, and mapped in Fig. 2 together with results by Farina et al. (1990). No ecological pattern was detected in the distribution of the pathogen.

Armillaria rhizomorphs were found at one third of the sampling points. However, Armillaria was widespread throughout the forest in soil $(88.5 \%$ positive soil samples based on PCR results). The most common species distinguished by restriction were $A$. ostoyae at 21 points ( $29 \%$ of rhizomorphs/ $37 \%$ of positive soil samples) and A. cepistipes at 20 points $(53 / 28)$. A. gallica was found at 16 points (18/31), while A. mellea was present in only 2 soil samples (0/4). A. cepistipes was twice more frequent in rhizomorph samples than in soil. The spatial distribution of Armillaria species identified from both sample types is shown in Fig. 3 . A. mellea was found only in silver fir-Doustands (where A. alba was growing sporad- 


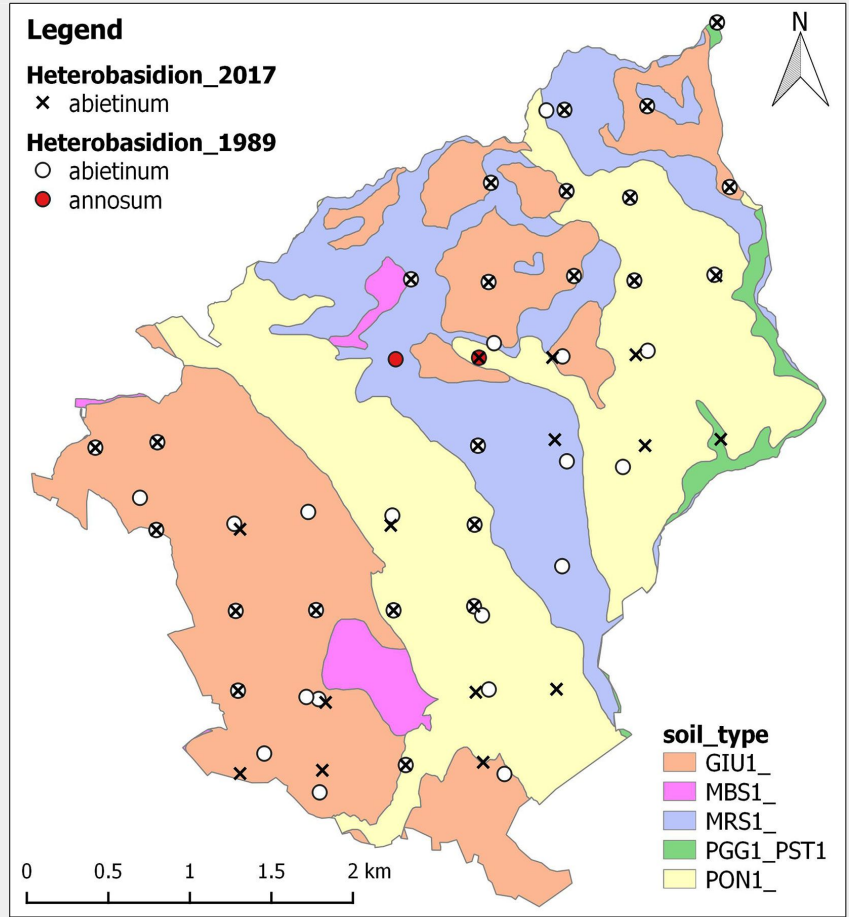

Fig. 2 - Spatial distribution map of Heterobasidion samples identified by Farina et al. (1990) and by present study (2015-2017). In some cases, where new host species were concerned or the damages from root rot were very evident, Farina et al. (1990) also collected material outside of the grid points. Soil types according to the Italian soil classification system and the Soil Survey Staff (1999): (GIU1) Giunchete - Ultic Hapludalfs; (MBS1) Monte Bastione - Typic Hapludalfs; (MRS1) Maresca - Humic Dystrudepts; (PGG1_PST1) Poggio di Petto - Lithic Dystrudepts; (PON1) Pontepetri - Typic Dystrudepts. (Source: http://159.213. 57.101/pmapper/map.phtml).

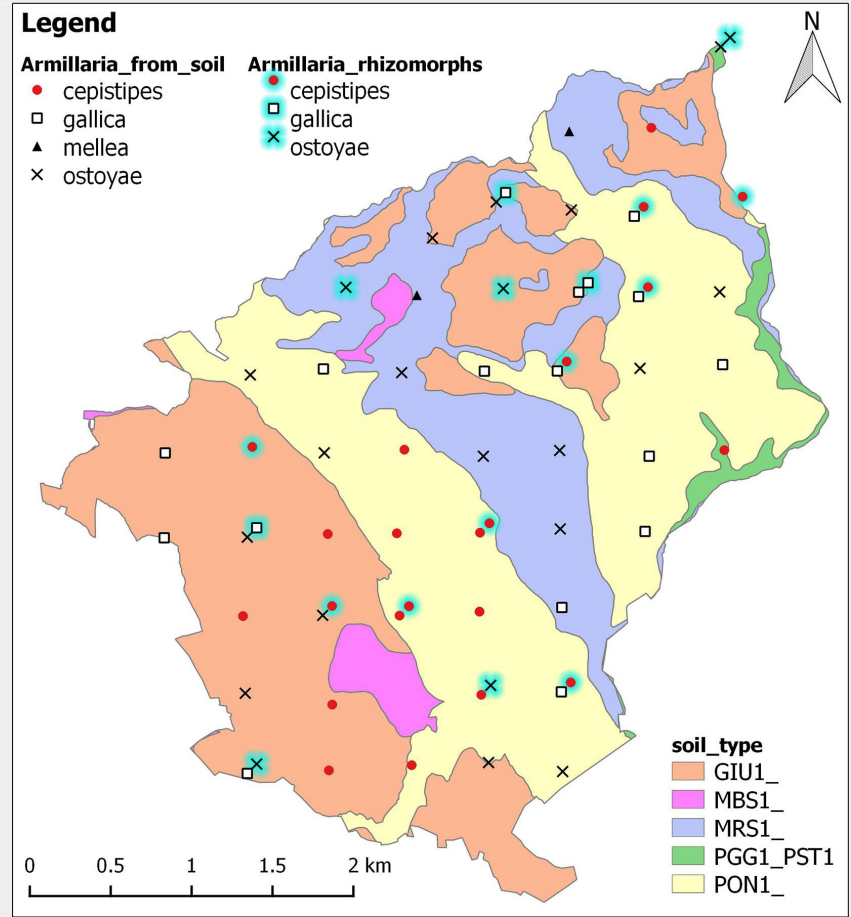

Fig. 3 - Spatial distribution map of Armillaria samples included in the study. Points with an outer glow indicate rhizomorph samples. Soil types according to the Italian soil classification system and the Soil Survey Staff (1999): (GIU1) Giunchete - Ultic Hapludalfs; (MBS1) Monte Bastione - Typic Hapludalfs; (MRS1) Maresca - Humic Dystrudepts; (PGG1 PST1) Poggio di Petto - Lithic Dystrudepts; (PON1) Pontepetri - Typic Dystrudepts (Source: http://159.213.57.101/pmapper/map.phtml). glas-fir mixed stands in Humic Dystrudepts (MRS1). A. cepistipes was mostly found in silver fir stands (70\%), while A. ostoyae and especially $A$. gallica more abundantly occurred in forests dominated by other tree species, particularly beech.

Effects of tree species composition (i.e., prevalent tree species in the stand) and

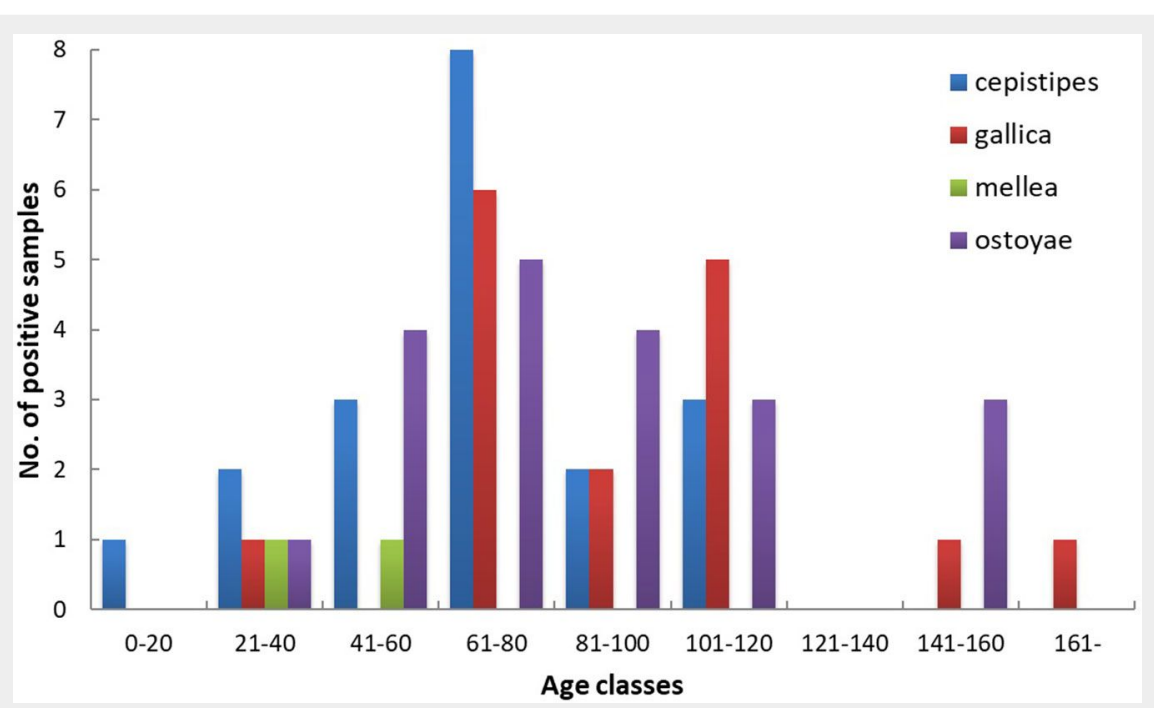

Fig. 4 - Distribution of Armillaria spp. according to age classes of the forest stands.

soil type were non-significant. Armillaria spp. were present at a wide range of elevations and various forest sites. There was no statistically significant difference found in the altitudinal distribution of Armillaria species. The difference between $A$. cepistipes and $A$. ostoyae occurrence can be explained by the effect of site fertility levels (coef. $=0.737, p=0.024$ ), the former species inhabits more productive sites. Another parameter that had a statistically significant effect on the distribution of the pathogen was the age of the stand. A. mellea was only present in pole stands. The majority of A. cepistipes were found in the 61-80 years age class, while the occurrences of $A$. gallica and $A$. ostoyae were shifted towards the oldest stands (Fig. 4). The difference between $A$. cepistipes and A. gallica occurrence can be explained by this pattern (coef. $=0.027, p=0.028$ ).

\section{Discussion}

The results of the study confirm and extend the knowledge about presence of Heterobasidion in the forest of Vallombrosa since the investigation by Farina et al. (1990). In that study, H. abietinum (F ISG) was found in the surrounding area of about $73 \%$ of the sampling points. The survey carried out in 2015-2017 confirmed the presence of the pathogen at all these points except for three. Nevertheless, in the present survey the fungus was recorded at two new localities at elevation of about $1100 \mathrm{~m}$ a.s.l. These detections indicate a possible expansion of the parasite at upward elevation, which might be associated with climate change (Yan et al. 2017). 
Contrastingly to the work by Farina et al. (1990), where H. annosum s.s. (P ISG) was detected in Vallombrosa at a very low frequency (4\% of sampling points), this species was not found in the forest in our survey. However, Farina et al. (1990) isolated the fungus also from wood samples gathered at each point, while the present survey was based solely on the apparent fruiting bodies. Indeed, basidiomes of $\mathrm{H}$. annosum s.s. might be more difficult to detect since they are less thick and less persistent than those produced by $\mathrm{H}$. abietinum (Niemelä \& Korhonen 1998).

Although the majority of $\mathrm{H}$. abietinum occurrences fell to fir stands, basidiomes of the fungus occasionally appeared in stands dominated by Douglas-fir, European black pine and beech, where there was admixture of silver fir. We did not identify the pathogen on other host species than Abies alba. However, in the forest of Vallombrosa H. abietinum had been reported on Norway spruce, Douglas-fir, chestnut, Japanese red-cedar and pine by Farina et al. (1990). Sedlák \& Tomšovsky (2014) reported H. abietinum on pine and Norway spruce in the Czech Republic, always in stands where the historical presence of $A$. alba was documented, supporting the evidence that the fungus can survive at sites with a changed tree species composition. Therefore the presence of the fungus might represent a threat for other tree species besides $A$. alba, especially conifers, but also deciduous trees when growing in mixture with conifers, or at difficult sites (Korhonen et al. 1998), on high pH (>6) soils (Redfern \& Ward 1998) or under the pressure of climate change, which is expected to be especially strong and sudden in the Mediterranean region (Giorgi 2006, Lionello et al. 2006) and which may defeat tree defences against secondary pathogens (Ghelardini et al. 2016). In the case of Douglas-fir, which is only occasionally attacked by the pathogen and seldom suffers early mortality and killing even at an older age (Delatour et al. 1998, Korhonen et al. 1998), the highest risk is posed by $\mathrm{H}$. abietinum to young individuals (Sala et al. 1995).

Regarding Armillaria species, the differences in their infection biology must be taken into account. Some species like $A$. cepistipes propagate directly in soil (Prospero et al. 2006), whereas others such as A. ostoyae are restricted to spreading through root contacts (Cruickshank et al. 1997). Therefore, the presence of DNA of distinct Armillaria spp. in soil does not necessarily correlate with their prevalence in the ecosystem.

Armillaria spp. are present in the entire area of the Nature Reserve of Vallombrosa. In many cases, the DNA of the fungus was amplified from both the rhizomorphs and the soil samples collected at the same location, and these isolates often belong to different species. This type of coexistence within the same forest stand is well documented in the literature (Prospero et al.
2006, Antonín et al. 2009), and has been explained by the different ecological strategy of the species, i.e., their specialization to saprophytic or parasitic behaviour.

In many respects, $A$. cepistipes seems to be the most influential Armillaria species in the Vallombrosa forest. The fact that more than half of the identified rhizomorph samples belong to this species is consistent with observations by many authors who describe it as highly rhizomorphogenic (Shaw \& Kile 1991). Most probably, A. cepistipes finds its ecological optimum in the area and consequently shows pathogenicity in weakened hosts such as pines. Our results foreshadow its ability to overcome host resistance even on the most fertile sites. Given its dominance in relatively young fir stands, this species is considered potentially hazardous in Vallombrosa. A. ostoyae is equally common as A. cepistipes, but its DNA was more often isolated from soil. Despite this species is usually associated with conifers, $38 \%$ of its occurrences in the forest of Vallombrosa were broadleaved stands. The third important species is A. gallica. This facultative parasite did not show any preference to forest type, is evenly distributed in the area. In the points where both species are present, $A$. cepistipes was found as rhizomorphs while $A$. gallica was determined from soil. This points to the fact that $A$. cepistipes acts as a parasite whereas $A$. gallica is a decomposer, which is in line with the abovementioned hypothesis of Prospero et al. (2006). Surprisingly, A. mellea was detected from Douglas-fir stands. European plantations of this species are considered resistant to Armillaria root rot (Guillaumin \& Legrand 2013). It is reasonable to assume that $A$. mellea is a residual from the previous rotation of broadleaves in these quite young stands rather than a colonizer of conifers.

Besides root rot disease, two factors are conceived to be crucial in silver fir decline. Soil properties decisively affect fir growth; at Vallombrosa, the high bulk density of the $B C$ horizon hinders deep rooting, thus limiting the stability of trees. Moreover, the almost impermeable layer prevents the soil from accumulating adequate amounts of water. Suffering from water stress, trees are unable to produce inhibitor metabolites for $\mathrm{H}$. abietinum, so their susceptibility increases to the infection (Certini et al. 2000). Mediterranean climate is not very well suited to the needs of silver fir either. In addition to long dry periods in summer, particular weather events, such as heavy snowfalls and cyclones put these conifers under stress (Puddu et al. 2003). The situation is getting worse with the advance of the global climate disruption (IPCC 2014).

\section{Conclusions}

Our results confirmed the widespread presence of root decaying fungi in the forest of Vallombrosa (central Italy). Review- ing the relevant literature has revealed an etiology in which soil properties and climatic circumstances are crucial elements, being able to predispose the trees to fungal infection and determine the disease outcome. When assessing the possibility of intervention to manage the forest so as to limit the damage from root rot caused by H. annosum s.l. and Armillaria spp., it is necessary to know the potential risk posed by the different species regarding their host spectrum, infection biology and ecological needs, considering their possible different behaviour with regard to the applied management strategies and interventions. Abies alba and Pinus spp. are known to be the most vulnerable tree species to these pathogens, but young Douglas-fir individuals may also suffer heavy damage by Heterobasidion attacks. Bearing in mind that the extent of damages at Vallombrosa has crossed a threshold where it does not merely cause large economic loss, but threatens the stability of the ecosystem (Chirici et al. 2018), it is advisable to apply practical measures to limit the spread of parasites that have a crucial role in weakening trees and mining their resistance to mechanical stress. Since the area is protected, drastic operations like stump removal are not allowed. Instead, preventive treatment on the stumps utilizing antagonistic fungi is recommended immediately after cutting to inhibit the airborne colonization by $\mathrm{H}$. abietinum and thus reduce the further extension of the rot through root contacts. Cuts should be done in summer when sporulation rate of Heterobasidion is low (Garbelotto et al. 2010). In the case of silver fir, lowering the rotation period to $100-120$ years is advisable. Fir stands should be planted only in the most suitable soils of the area, Ultic Hapludalfs (GIU1). Planting of Douglas-fir in areas where the presence of Heterobasidion is documented should be avoided. Creating mixed stands with broadleaves is a preference; as such forests are less susceptible to Heterobasidion (Puddu et al. 2003) and Armillaria (Guillaumin \& Legrand 2013) attacks. Our results may help forest managers to decide which tree species are to be planted, based on their resistance to root rot pathogens.

\section{Acknowledgements}

Data collection has been done in frame of Erasmus+ internship at the Department of Agrifood Production and Environmental Sciences (DISPAA), University of Florence, Italy. We wish to thank Lorenzo Allighieri and Chiara Aglietti for their help in the field. Samples were analysed in the laboratories of the Department of Forest Protection and Wildlife Management and the Department of Forest Botany, Dendrology and Geobiocoenology, Faculty of Forestry and Wood Technology, Mendel University in Brno, Czech Republic. We are grateful for Ing. Petr Sedlák, Ph.D. and Ing. Tomáš Májek for their guidance during laboratory analyses. Special thanks go to the Interna- 
tional Visegrad Fund for supporting the corresponding author's academic studies by Intra-Visegrad Scholarship.

\section{References}

Antonín V, Jankovsky L, Lochman J, Tomšovsky M (2006). Armillaria socialis - morphologicalanatomical and ecological characteristics, pathology, distribution in the Czech Republic and Europe and remarks on its genetic variation. Czech Mycology 58 (3-4): 209-224. - [online] URL: http://citeseerx.ist.psu.edu/viewdoc/ download?doi=10.1.1.538.4418\&rep=rep1\&type= pdf

Antonín V, Tomšovsky $M$, Sedlák $P$, Májek $T$, Jankovsky $L$ (2009). Morphological and molecular characterization of the Armillaria cepistipes - A. gallica complex in the Czech Republic and Slovakia. Mycological Progress 8 (3): 259-271. doi: 10.1007/s11557-009-0597-1

Bolla G (2001). Distribuzione, caratterizzazione e genesi degli orizzonti compatti nei suoli della foresta di Vallombrosa (Firenze). Loro influenza sul ribaltamento dell'abete bianco [Distribution, characterization and genesis of compacted horizons in soils of the Vallombrosa forest (Florence). Their influence on the uprooting of silver fir]. Bachelor's thesis, Faculty of Agricultural and Forest Science, University of Florence, Italy. [in Italian]

Cantiani M (1960). Note sulla diffusione del marciume radicale nelle abetine di Vallombrosa [The extent of root rot in the Abies alba stands of Vallombrosa]. L'Italia Forestale e Montana 15: 122-124. [in Italian]

Capretti P (1998). Italy. In: "Heterobasidion annosum: biology, ecology, impact, and control" (Woodward S, Stenlid J, Karjalainen R, Hüttermann $A$ eds). $C A B$ International, Wallingford, UK, pp. 377-385.

Certini G, Corti G, Ugolini FC (2000). Influence of soil properties on the mortality of silver fir in Tuscany, Italy. Forstwissenschaftliches Centralblatt 119: 323-331. - doi: 10.1007/BF02769147 Chirici G, Bottalico F, Giannetti F, Del Perugia B, Travaglini D, Nocentini S, Kutchartt E, Marchi E, Foderi C, Fioravanti $M$, Fattorini L, Bottai L, McRoberts RE, Corona P, Gozzini B (2018). Assessing forest windthrow damage using singledate, post-event airborne laser scanning data. Forestry 91 (1): 27-37. - doi: 10.1093/forestry/cpx 029

Cruickshank MG, Morrison DJ, Punja ZK (1997). Incidence of Armillaria species in precommercial thinning stumps and spread of Armillaria ostoyae to adjacent Douglas-fir trees. Canadian Journal of Forest Research 27 (4): 481-490. doi: $10.1139 / \times 96-185$

Delatour C, Von Weissenberg K, Dimitri L (1998). Host resistance. In: "Heterobasidion annosum: biology, ecology, impact, and control" (Woodward S, Stenlid J, Karjalainen R, Hüttermann A eds). CAB International, Wallingford, UK, pp. 143-166.

Farina P, Capretti P, Mugnai L (1990). Gruppi intersterili di Heterobasidion annosum: osservazioni nella foresta di Vallombrosa [Intersterility groups of Heterobasidion annosum: an investigation in the forest of Vallombrosa]. L'Italia Forestale e Montana 45 (5):347-360. [in Italian] Garbelotto M, Linzer R, Nicolotti G, Gonthier P
(2010). Comparing the influences of ecological and evolutionary factors on the successful invasion of a fungal forest pathogen. Biological Invasions 12: 943-957. - doi: 10.1007/s10530-009-9 514-4

Chelardini L, Pepori AL, Luchi N, Capretti P, Santini $A$ (2016). Drivers of emerging fungal diseases of forest trees. Forest Ecology and Management 381: 235-246. - doi: 10.1016/j.foreco.20 16.09 .032

Giorgi F (2006). Climate change hot-spots. Geophysical Research Letters 33 (8): L08707. - doi: 10.1029/2006GL025734

Gonthier P, Garbelotto M, Nicolotti G (2003). Swiss stone pine trees and spruce stumps represent an important habitat for Heterobasidion spp. in subalpine forests. Forest Pathology 33: 191-203. - doi: 10.1046/j.1439-0329.2003.00323.x Gonthier P, Thor M (2013). Annosus root and butt rots. In: "Infectious forest diseases" (Gonthier P, Nicolotti G eds). CAB International, Wallingford, UK, pp. 128-158. - doi: 10.1079/9781 780640402.0128

Gori Y, Cherubini P, Camin F, La Porta N (2013). Fungal root pathogen (Heterobasidion parviporum) increases drought stress in Norway spruce stand at low elevation in the Alps. European Journal of Forest Research 132: 607-619. doi: 10.1007/s10342-013-0698-x

Gregow H, Laaksonen A, Alper ME (2017). Increasing large scale windstorm damage in Western, Central and Northern European forests, 1951-2010. Scientific Reports 7: 46397. doi: $10.1038 /$ srep46397

Guillaumin JJ, Legrand P (2013). Armillaria root rots. In: "Infectious forest diseases" (Gonthier $P$, Nicolotti $G$ eds). CAB International, Wallingford, UK, pp. 159-177. - doi: 10.1079/9781780640 402.0159

Guillaumin JJ, Mohammed C, Anselmi N, Courtecuisse R, Gregory SC, Holdenrieder O, Intini M, Lung B, Marxmüller H, Morrison D, Rishbeth J, Termorshuizen AJ, Tirro A, Van Dam B (1993). Geographical distribution and ecology of the Armillaria species in Western Europe. European Journal of Forest Pathology 23 (6-7): 321-341. doi: 10.1111/j.1439-0329.1993.tboo814.x

Haavik LJ, Billings SA, Guldin JM, Stephen FM (2015). Emergent insects, pathogens and drought shape changing patterns in oak decline in North America and Europe. Forest Ecology and Management 354: 190-205. - doi: 10.1016/j.foreco.2015.06.019

Holuša J, Lubojacký J, Curn V, Tonka T, Lukášová K, Horák J (2018). Combined effects of drought stress and Armillaria infection on tree mortality in Norway spruce plantations. Forest Ecology and Management 427: 434-445. - doi: 10.1016/ j.foreco.2018.01.031

Honkaniemi J, Lehtonen $\mathrm{M}$, Väisänen $\mathrm{H}$, Peltola $H$ (2017). Effects of wood decay by Heterobasidion annosum on the vulnerability of Norway spruce stands to wind damage: a mechanistic modelling approach. Canadian Journal of Forest Research 47 (6): 777-787. - doi: 10.1139/cjfr2016-0505

Intini MG (1988). The association of Armillaria ostoyae (Romagnesi) Herink with death of white firs in Italy. Informatore fitopatologico 38 (4): 67-70. [in Italian with English summary]

IPCC (2014). Climate change 2014: synthesis re- port. Contribution of Working Groups I, II and III to the Fifth Assessment Report of the Intergovernmental Panel on Climate Change (Core Writing Team, Pachauri RK, Meyer LA eds). IPCC, Geneva, Switzerland, pp. 151.

Jankovsky L (2003). Distribution and ecology of Armillaria species in some habitats of southern Moravia, Czech Republic. Czech Mycology 55 (3-4): 173-186.

Korhonen K (1978a). Interfertility and clonal size in the Armillariella mellea complex. Karstenia 18: 31-42. - doi: 10.29203/ka.1978.135

Korhonen K (1978b). Intersterility groups of Heterobasidion annosum. Communicationes Instituti Forestalis Fenniae 94: 1-25. [online] URL: http://www.cabdirect.org/cabdirect/abstract/19 820678136

Korhonen K, Delatour C, Greig BJW, Schönhar S (1998). Silvicultural control. In: "Heterobasidion annosum: biology, ecology, impact, and control" (Woodward S, Stenlid J, Karjalainen R, Hüttermann $A$ eds). CAB International, Wallingford, UK, pp. 283-313.

Kubiak K, Zólciak A, Damszel M, Lech P, Sierota Z (2017). Armillaria pathogenesis under climate changes. Forests 8 (4): 100. - doi: 10.3390/f804 0100

La Porta N, Capretti P, Thomsen IM, Kasanen R, Hietala AM, Von Weissenberg K (2008). Forest pathogens with higher damage potential due to climate change in Europe. Canadian Journal of Plant Pathology 30 (2): 177-195. - doi: 10.1080/ 07060661.2008.10540534

Lionello P, Malanotte-Rizzoli P, Boscolo R (2006). Mediterranean climate variability. Elsevier, Amsterdam, the Netherlands, pp. 438. [online] URL: http://books.google.com/books? id=JD8CqjuA4SAC

Lochman J, Sery O, Jankovsky L, Mikeš V (2004a). Variations in rDNA ITS of Czech Armillaria species determined by PCR and HPLC. Mycological Research 108 (10): 1153-1161. - doi: 10.1017/So953756204000644

Lochman J, Sery O, Mikeš V (2004b). The rapid identification of European Armillaria species from soil samples by nested PCR. FEMS Microbiology Letters 237: 105-110. - doi: 10.1111/j.15746968.2004.tbog684.x

Manion PD (1981). Tree disease concepts. Prentice Hall, New York, USA, pp. 399.

Moriondo F, Tiberi R (2000). Aspetti fitopatologici delle abetine di Vallombrosa [Phytopathological aspects of silver fir stands in Vallombrosa]. L'Italia Forestale e Montana 55 (6): 369-380. [in Italian]

Mugnai L, Capretti P (1989). Intersterility groups of Heterobasidion annosum (Fr.) Bref.: some morphological differences in the basidiocarps. Micologia Italiana 3: 87-94.

Müller MM, Sievänen R, Beuker E, Meesenburg H, Kuuskeri J, Hamberg L, Korhonen K (2014). Predicting the activity of Heterobasidion parviporum on Norway spruce in warming climate from its respiration rate at different temperatures. Forest Pathology 44 (4): 325-336. - doi: 10.1111/efp.12104

Niemelä T, Korhonen K (1998). Taxonomy of the genus Heterobasidion. In: "Heterobasidion annosum: biology, ecology, impact, and control" (Woodward S, Stenlid J, Karjalainen R, Hüttermann A eds). CAB International, Wallingford, 
UK, pp. 27-33.

Otrosina WJ, Garbelotto M (2010). Heterobasidion occidentale sp. nov. and Heterobasidion irregulare nom. nov.: a disposition of North American Heterobasidion biological species. Fungal Biology 114: 16-25. - doi: 10.1016/j.mycres. 2009.09.001

Prospero S, Holdenrieder O, Rigling D (2006). Rhizomorph production and stump colonization by co-occurring Armillaria cepistipes and Armillaria ostoyae: an experimental study. Forest Pathology 36 (1): 21-31. - doi: 10.1111/j.14390329.2006.00426.x

Puddu A, Luisi N, Capretti P, Santini A (2003). Environmental factors related to damage by Heterobasidion abietinum in Abies alba forests in Southern Italy. Forest Ecology and Management 180: 37-44. - doi: 10.1016/S0378-1127(02)oo 607-2

Redfern DB, Ward D (1998). The UK and Ireland. In: "Heterobasidion annosum: biology, ecology, impact, and control" (Woodward S, Stenlid J, Karjalainen $\mathrm{R}$, Hüttermann A eds). CAB International, Wallingford, UK, pp. 347-354.
Sala M, Menguzzato G, Capretti P (1995). Attacchi di Heterobasidion annosum in piantagioni di douglasia [Attacks by Heterobasidion annosum to Douglas-fir stands]. Annali dell'Istituto Sperimentale di Selvicoltura 24: 37-48. [in Italian]

Sedlák P, Tomšovsky M (2014). Species distribution, host affinity and genetic variability of Heterobasidion annosum sensu lato in the Czech Republic. Forest Pathology 44 (4): 310-319. doi: 10.1111/efp.12102

Shaw CG, Kile GA (1991). Armillaria root disease. Agriculture Handbook 691, USDA Forest Service, Washington, DC, USA, pp. 233.

Soil Survey Staff (1999). Soil taxonomy. A basic system of soil classification for making and interpreting soil surveys ( $2^{\text {nd }}$ edn). Agriculture Handbook Number 436, USDA Natural Resources Conservation Service, US Government Printing Office, Washington, DC, USA, pp. 886. StatSoft (2013). STATISTICA (data analysis software system), version 12 . Web site. [online] URL: http://www.tibco.com/products/tibco-stat istica

Svetasheva T (2015). Armillaria ectypa. The IUCN red list of threatened species 2015: e.T750 97245A75098379. - doi: 10.2305/IUCN.UK.20154.RLTS.T75097245A75098379.en

White TJ, Bruns T, Lee S, Taylor J (1990). Amplification and direct sequencing of fungal ribosomal RNA genes for phylogenetics. In: "PCR protocols: a guide to methods and application" (Innis MA, Gelfand DH, Sninsky JJ, White TJ eds). Academic Press, San Diego, CA, USA, pp. 315-322. - doi: 10.1016/B978-0-12-372180-8.50042-

Yan Y, Li Y, Wang W, He J, Yang R, Wu H, Wang $X$, Jiao L, Tang Z, Yao $Y$ (2017). Range shifts in response to climate change of Ophiocordyceps sinensis, a fungus endemic to the Tibetan Plateau. Biological Conservation 206: 143-150. doi: 10.1016/j.biocon.2016.12.023

\section{Supplementary Material}

Tab. S1 - GPS data of sampling points.

Link: Dalya_2929@supplo01.pdf 